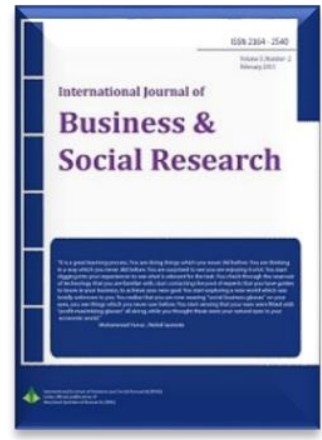

\title{
Natural Resources and FDI in GCC Countries
}

\author{
Mohamed Elheddad'
}

\begin{abstract}
Natural resources are a blessing for some countries to attract FDI but cursed for others. Existing literature argues the suggestion that resource-rich countries attract less FDI because of resource (oil) price volatility. This study examines that natural resources discourage FDI in GCC countries (the FDINatural resources curse hypothesis), using panel data analysis for six oil dependent countries during 1980-2013 and applying several econometrics techniques. The main findings of this paper is that natural resources measured by oil rents have a negative association with FDI inflows; this negative impact is robust even when other FDI determinates of FDI are included. FDI inflows decreased between 0.15 and $0.92 \%$ when oil rents increased by $1 \%$. In addition, the empirical results show that trade openness and labour force are the main factors that encourage FDI, while political instability and corruption deter FDI inflows into GCC countries.
\end{abstract}

Keywords: Economic growth, endogeneity, FDI, GCC region, natural resources, panel data.

JEL Codes: F21, Q33, Q35, C23 L72, O13.

Available Online: 12-08-2016

This is an open access article under Creative Commons Attribution 4.0 License, 2016.

\section{$1.0 \quad$ INTRODUCTION}

In recent years, Foreign Direct Investment (FDI) has been considered as a crucial way of transforming technologies, boosting economic growth and reducing poverty worldwide. Therefore, policy makers in both developed and developing countries have introduced policies to attract more FDI. According to the United Nations Conference on Trade and Development (UNCTAD), foreign capital inflows are important to the host country, as inward FDI contributes to economic growth through providing new knowledge, job creation, and supporting competitiveness (Asiedu, 2013).

However, recent literature has observed that some resource-abundant countries attract less FDI than other countries which are resource-poor countries (Asiedu, 2013; Poelhekke \& Van der Ploeg, 2010, 2013). These studies also noted that FDI inflows to resource countries concentrated on resource sectors such as oil, diamonds, gas or gold. Investing in these industries could generate unbalanced development in the host countries and tend not to create positive spill-over of FDI. In other words, the resource sector

1 University of Hull, Hull Business School (HUBS), United Kingdom 
crowds out non-resource sector investment. A more specific case is GCC countries. In Qatar, resource FDI constitutes for more than $65 \%$ of total FDI, and FDI in the resource sector in Saudi Arabia stands at about $70 \%$ of total FDI. ${ }^{2}$ In this light, FDI can be seen as an additional vehicle curtailing economic growth under the concept of natural resources curse.

To provide more understanding about this issue, Figure1 depicts the trend of FDI broken down into primary, manufacturing and service sectors. It shows that FDI as a percentage of GDP in the mining sector has exhibited a decreasing trend since 2003; its share in total FDI inflows ranged from $4.29 \%$ to $19 \%$. While the share of manufacturing and service sectors have witnessed dramatic shifts during the same period averaged between $46 \%$ and $43 \%$ at the same time, FDI as absolute values (Millions of Dollars) manufacturing and service divisions have absorbed a large share compared with primary sector.

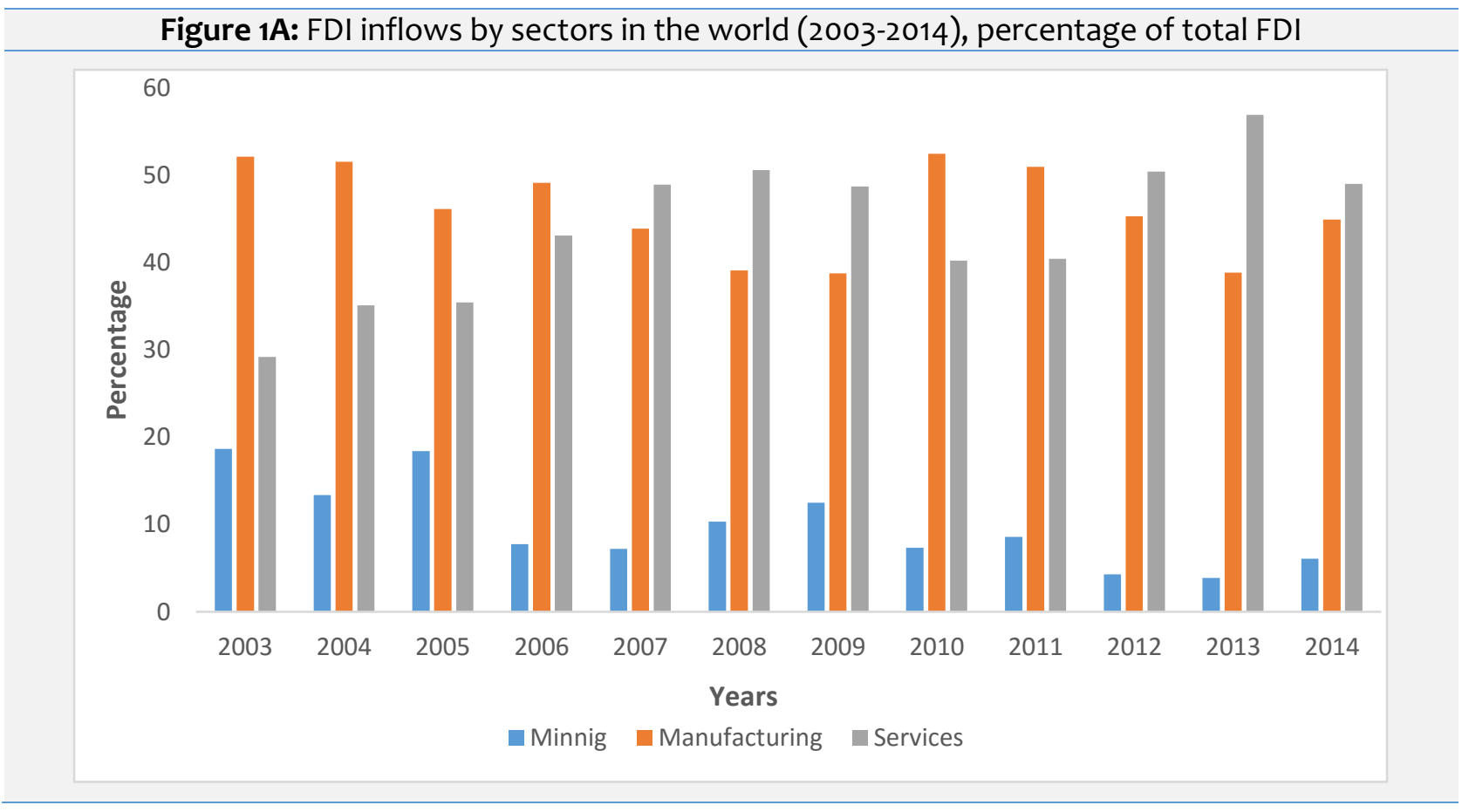

Figure 2B: FDI inflows by sectors in the world (2003-2014), in millions of dollars

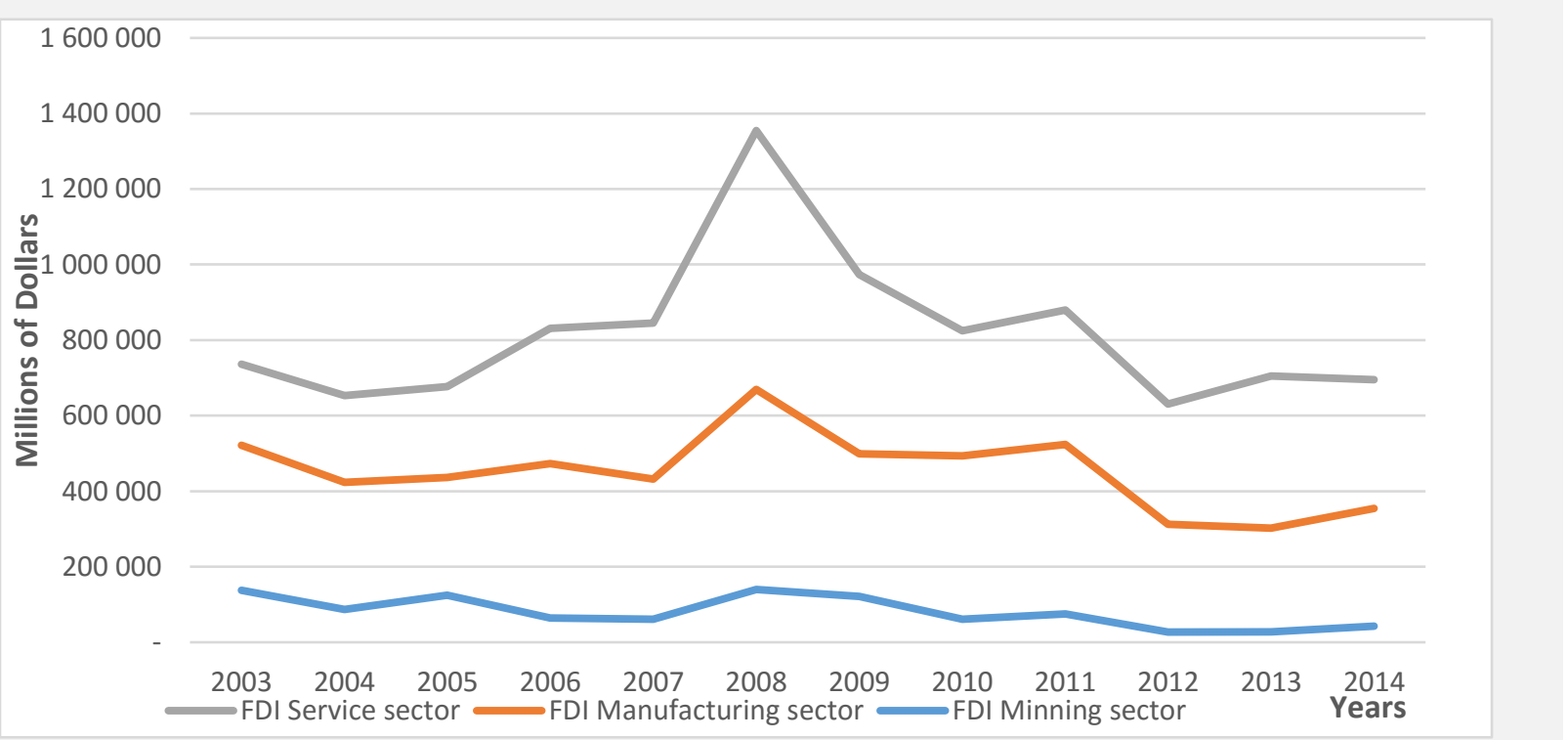

Source: Author's work depending on data from World Investment Report 2015 (UNCTAD, 2015)

\footnotetext{
2 Author's calculations depending on the dataset of FDI intelligence
} 
For GCC countries, figure 2 plots the correlation between the natural resources measured by oil revenues as a percentage of GDP and FDI inflows. This graph indicates that there is a significant negative correlation between these two variables during 1980-2013, with a correlation coefficient of $-0.35 \%$. This figure may raise a question about the relationship between natural resources and FDI in this region and suggests the likelihood of FDI-natural resource curse thesis in GCC countries.

The purpose of this paper is to identify the impact of a natural resource on the amount of FDI in Gulf Cooperation Council countries during the period (1980-2013).The paper contributes to the literature in two aspects. First, it investigates the natural resource impact on FDI movement in the context of the resource curse. Second, this paper is the first empirical work using recent oil revenues data as a proxy for natural resources in the GCC region.

Figure 2: Scatter plots FDI and Oil Revenues in GCC countries during (1980-2013)

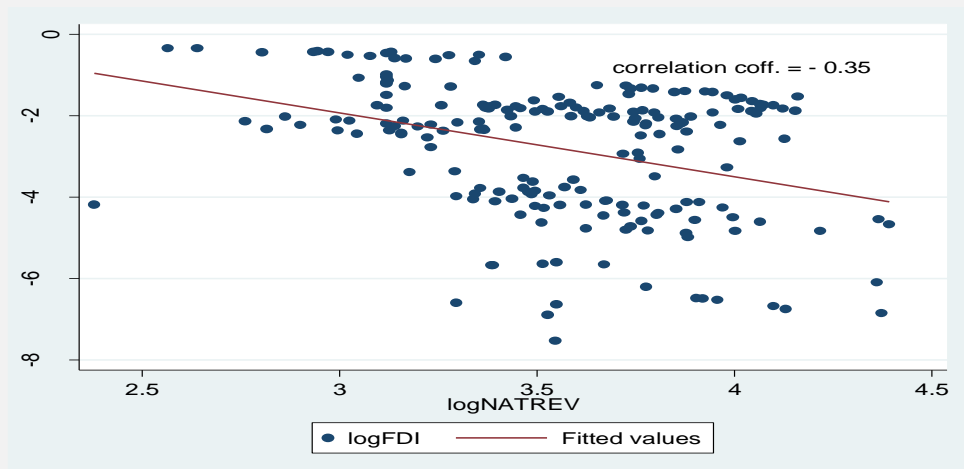

Source: STATA output, Author's work depending on data from UNCTAD and World Bank (World Bank, 2015).

\subsection{REVIEW OF LITERATURE}

There is a widespread idea that countries rich in natural resources such as oil, gas, diamonds or gold, motivate more FDI, but this is not always the case. The impact of natural resources on FDI is still a controversial issue, with evidence of inducing positive and negative effects. WDI (2013) noted that " countries that rely on heavily on extractive industries have seen large increases in natural resource rents, but their growth will not be sustainable unless they invest in productive assets" (Bokpin, Mensah, \& Asamoah, 2015)

The effect of natural resources can be investigated from two perspectives. First through growth channel and the demand side (determinants). Alfaro (2003) raised the question whether FDI in primary, manufacturing and services sectors yield different effects on a country's growth. Alfaro applied panel data for 47 countries from different regions during (1981-1999) using FDI inflow to all sectors as independent variables and Average real annual per capita growth rate as the dependent variable. Alfaro noted that foreign capital in primary sectors causes a negative impact on economic growth, while FDI in manufacturing and service sectors encourage economic growth. The results show that one unit increase in primary sector FDI leads to a (0.17-0.32) unit fall in economic growth. Regarding GCC region, Mina (2007) looked at the location determinants of FDI for the period 1980-2002 using panel data analysis. Mina's results indicate that natural resources measured by oil reserves have a remarkably negative impact on FDI flows. Also, human development is negatively associated with FDI flows to the Gulf area. Nevertheless, the literature on determinants of FDI inflows reported that natural resources is one of the most attractive factors of MNCs. Asiedu (2006) pointed out that the mineral and oil exports-total exports ratio as a proxy of natural resource has a significant role in attracting FDI inflows, taking 22 African countries as a sample during (1984-2000) and using panel data analysis. The results of Aseidu's study show that one standard deviation increase in natural resources results a $0.65 \%$ rise in FDI ratio. In the same line, in 45 African countries, Hailu (2010) examined the demand side factors affecting foreign capital inflows over the period 1980 and 2007. Hailue found that natural resource (mineral depletion as a share 
in $\mathrm{GNI}$ ) is positively and significantly correlated with FDI ratio. A One per cent increase in natural resources results in impact between 0.500 and 0.19 per cent. Further, Kinoshita \& Campos (2003) investigated the determinants of FDI inflows to 25 transition economies between 1990 and 1998 using unique panel data; this study concludes that natural resources are the key factor for attracting FDI to this area along with institutions, openness and agglomeration.

Recent literature has focused on the specific relationship between FDI inflows, outflows, and natural resources. These studies considered the crowding effect, "Dutch Disease", through FDI channels. Poelhekke and van der Ploeg (2010) among the earliest works has tried to shed light on this issue. They examine whether natural resources attract FDI, covering outflows FDI from Dutch firms to 183 countries for the years 1984-2002 applying a gravity panel data model. By differentiating between FDI outflows to resource sectors and non-resource sectors, they established two econometric models one for resource FDI and another for non-resource FDI. Their estimations showed that subsoil assets as a proxy of natural resources induce an adverse impact on non-resource FDI, but have a positive effect on resource FDI. Also, they found that the net effect of resource abundance on total FDI quickly becomes negative using a simulation exercise (FDI become negative four years after shock in Australia whereas it became negative two years after shock in Norway). One of the surprising results is that institutional quality and trade openness have no significant effects on FDI in the non-resource sector while the institutional quality does have a positive role on resource FDI.

These results are further explained in Poelhekke and van der Ploeg (2013) with the same sample in the same period. They reported that in previously non-resource countries, discovering resources led to nonresource $\mathrm{FDI}$ to decreasing by $16 \%$ in the short term and by $68 \%$ in the long term. In addition, for resource countries, a doubling of resource rents causes a $12.4 \%$ decline in resource FDI, and total FDI falls by $4 \%$ if the resource rents are doubled.

Additionally, Asiedu (2013) evidence that contradicts her earlier study in 2002, Asiedu (2013) revealed a negative connection between natural resources (defined as the share of fuel exports in total reports and oil rents-GDP ratio). She used the GMM method to regress net FDI inflows-GDP ratio on natural resources, institutional quality and some control variables like trade openness, inflation and GDP per capita in 99 developing countries during 1984-2011. The results of this study illustrate that natural resource have a negative effect on FDI by 0.05. This result was consistent with Poelhekke and van der Ploeg (2010, 2013), but Asiedu (2013) concluded that high quality of institutions could mitigate the adverse influence of natural resources and criticised Poelhekke and van der Ploeg conclusions by using a variety of different measures of institutional quality. Asiedu described this negative relationship as a crowding out effect. Kinoshita \& Campos (2003) investigated the determinants of FDI inflows to 25 transition economies during 1990-1998 using unique panel data. They found that natural resource abundance attracted more FDI to these countries.

The main hypothesis of this study is that there is a negative relation between FDI and natural resource in GCC countries as a result of oil price fluctuations which means a high risk, foreign investors are not interested to invest in these market. Also this study tries to investigate the impact of other institutional and political factors on FDI.

\subsection{DATA, MODEL, AND METHODOLOGY}

In the standard literature, the ratio of FDI to GDP is commonly used as a proxy of FDI (Asiedu 2013) Our independent variables are constrained by the availability of data. For instance, data for taxes and real wages are not available in developing countries, in particular, GCC countries. This may explain the scarcity of studies in this area.

To test the validity of FDI-Natural resources curse, this study focuses on two main variables: FDI and natural resources. It also considers some control variables. 
Our empirical analyses utilize panel data of 6 oil-dependent developing countries over the period 19802013. Data have been collected from different sources as follows: trade openness and Oil revenues collected from the World Bank, FDI, inflation rate and GDP per capita collected from UNCATD and political instability and corruption perception index from the ICRG dataset.

As a natural resource proxy, we employ oil rents as a share of GDP as a measure of resource dependence (Asiedu 2013; Poelhekke and van der Ploeg 2013) It is worth mentioning that a high/low Oil rents/GDP ratio indicates the high/low diversification of the country. We hypothesize a negative relationship between natural resources and aggregate FDI. This argument is based mainly on the puzzle of the resource curse.

Our hypothesis relies on the idea that resource boom tends to lead to appreciation of country's currency, as a result of that, non-tradable exports will be less competitive. By this means the resource sector crowds out non-resource sectors regarding FDI (Poelhekke and van der Ploeg 2010, 2013). Also, natural resources, especially oil, is more fluctuated which makes the country more vulnerable to external shocks. At the end of the day, FDI flies from the oil sector to the non-resource sector, but this non-resource sector is less competitive in the world market. This can be an additional channel of the resource curse.

Following the previous literature, we examine the determinants of FDI inflow to GCC countries. The expected model is as follows

$$
\left(\frac{\text { FDIinfl }}{G D P}\right)_{i t}=\beta 1++\beta 2 \text { Oil }- \text { reveues }_{i t}+\beta 3 X_{i t}+\varepsilon_{i t} \quad \text { Eq. (01) }
$$

Where FDI inflow is real FDI inflows to GCC countries, GDP is real Gross Domestic Product constant 2005, $X_{i t}$ is the vector of control variables including: trade openness, Market size, Labour force, Political instability and corruption.

The hypothesis of this study is that if $\beta 2<0$ this refers to FDI-Natural resource curse (crowding-out), but if $\beta 2>0$ means that there is a crowding-in effect.

The descriptive statistics of the variables are reported in Table 1

\begin{tabular}{lrrr}
\hline \multicolumn{4}{c}{ Table 1: Descriptive statistics } \\
\hline & $(1)$ & $(2)$ & $(3)$ \\
\hline Variables & $\mathrm{N}$ & mean & Std. Dev. \\
\hline Log(FDI) & 203 & -2.766 & -2.766 \\
Log(openness rate) & 204 & -0.337 & -0.337 \\
Log(oil-revenues/GDP) & 198 & 3.564 & 0.378 \\
Log(Labour Force) & 204 & 6.818 & 6.818 \\
Log(GDP per capita) & 204 & 10.03 & 10.03 \\
Political Instability & 178 & 2.690 & 2.690 \\
Corruption perception Index & 178 & 3.459 & 3.459 \\
Inflation rate & 204 & 2.777 & 2.777 \\
Number of N & 6 & 6 & 6 \\
\hline
\end{tabular}

\subsection{RESULTS AND DISCUSSION}

This paper uses long panel data for the period 1980- $2013(\mathrm{~T}=34, \mathrm{~N}=6)$. Thus, the first stage in evaluating the empirical results is to check for spurious regression. This can be done by applying panel data unit root tests. This paper uses four different panel unit root tests. They are Im, Pesaran and Shin (IPS), Levin, Lin and Chu (LLC), Augmented Dicky Fuller (ADF) and Phillips-Perron (PP) ${ }^{3}$. Appendix B presents the results

3 Null hypothesis is unit root in common sample and individuals. 
of stationarity tests, these results confirm that all variables are stationary at the first difference. As a result of that we apply panel co-integration tests in order to make sure that there is a long-run relationship between the variables of the model. Appendix $C$ gives the results of Kao test and JohansenFisher panel co-integration, which means there is an association between variables in the long run.

The second step is to check other econometric problems. The main issue is the endogeneity problem; there is a possibility that unobserved variable may affect both FDI and natural resources. (Asiedu \& Lien, 2011). This problem can be mitigated by using GMM and an instrumental variables estimator as it is discussed later in section 4.1. The second problem is the correlation between time-invariant country and explanatory variables. This can be solved by applying a fixed effect model.

First, we depart from analysing natural resource and FDI relationship using Panel correction standard error(PCSE) because our sample is long panel data $(T=34$ greater than $N=6)$. Hence, this method is more suitable than POLS (Cameron, 2010), We then apply a fixed effects model (FE) and Random effect model. The second part re-estimates the same model taking into account the issue of endogeneity and the impact of business cycle fluctuations through using the GMM method, instrumental variable estimator, and averaging data in 5 years.

Table2, column1, PCSE results show that in GCC countries, high dependence on oil (natural resources) hampers FDI inflows. An increase in the oil revenues ratio by one percent leads to $0.97 \%$ decrease in FDI inflows; this impact is significant at the $\%$ level.

Afetr checking the Hausman test, it shows that the fixed effect model is appropiate for this estimation. The fixed effect model controls for the expected heterogeneity between countries. The results show the negative relationship between natural resources and FDI still holds, but is not significant. The coefficient of natural resources is -0.28 .

Furthermore, we find that the usual determinants of FDI, such as Labour Force and trade openness significantly attract FDI inflows, while corruption and political stability in the host country deter FDI inflows. A high level of corruption mitigates the FDI inflows to GCC countries by $1 \%$. This result is consistent with previous literature. In the same way, high political instability will depress foreign capital to GCC countries.

\subsection{ISSUE OF ENDOGENEITY}

So far the estimations have not considered the problem of endogeneity. It is important to note that the regression might be biased. There is a possibility that unobserved variables may affect both FDI and natural resources (Oil-GDP ratio). Therefore, we apply two different techniques to eliminate the existence of endogeneity.

The first is GMM method (System and difference) (Arellano \& Bond, 1991) and (Blundell \& Bond, 1998).

The second is the instrumental variables approach and using the GDP share of oil in total GDP lagged one year as an instrumental variable because it is argued that this variable is strongly exogenous. Its exogeneity can be rationalized as follows: oil production is usually extracted by foreign firms in GCC countries and using their technologies, making oil production relatively independent of unobserved development indicators. Also, lagged values are arguably exogenous.

In order to increase the results credibility, let us now test the FDI-natural resources curse using different estimators. According to GMM results, the coefficient estimated on oil revenues remains negative and significant at 5 and 10\%. This negativity ranges between 0.26 and 0.35 for system and difference GMM respectively. The Hansen test for over-identification restrictions confirms the validity of the instrumental variables. These kind of results give the model more robustness. 
Table 2: The relationship between FDI and natural resources: Benchmark estimations

(1) (2)

Variables

Panel Correction Standard Error Fixed Effect model

Dependent variable: $\log (\mathrm{FDI})$

Log(oil revenues)

\begin{tabular}{rr}
$-0.973^{* * *}$ & -0.287 \\
$(0.222)$ & $(0.207)$ \\
$0.631^{* * *}$ & $0.448^{* * *}$ \\
$(0.0496)$ & $(0.105)$ \\
$0.635^{* * *}$ & $0.916 * * *$ \\
$(0.0802)$ & $(0.146)$ \\
$-0.358^{* *}$ & $1.526 * * *$ \\
$(0.155)$ & $(0.272)$ \\
$-0.332^{* * *}$ & $-0.0889^{* *}$ \\
$(0.0472)$ & $(0.0433)$ \\
$-1.049 * * *$ & -0.0331 \\
$(0.199)$ & $(0.109)$ \\
0.000550 & $-0.0299 *$ \\
$(0.0203)$ & $(0.0153)$ \\
$4.791^{*}$ & $-22.60 * * *$ \\
$(2.453)$ & $(2.930)$ \\
172 & 172 \\
0.536 & 0.652 \\
6 & 6 \\
\hline
\end{tabular}

Log(openness)

Table 3: The relationship between FDI and natural resources: Robustness estimation

Observations

(3)

(4)

\begin{tabular}{|c|c|c|}
\hline $\begin{array}{l}\text { Variables } \\
\text { Dependent variable: } \log (\text { FDI })\end{array}$ & GMM & $\begin{array}{r}\text { Instrumental Variables } \\
\text { estimator }\end{array}$ \\
\hline L. $\log (F D I)$ & $\begin{array}{l}1.003^{* * *} \\
(0.0662)\end{array}$ & \\
\hline L2.log(FDI) & $\begin{array}{r}-0.168 * * * \\
(0.0565)\end{array}$ & \\
\hline Log (Oil revenues) & $\begin{array}{r}-0.150 \\
(0.108)\end{array}$ & $\begin{array}{r}-0.973^{* * *} \\
(0.240)\end{array}$ \\
\hline Log (openness) & $\begin{array}{l}0.163^{* * *} \\
(0.0538)\end{array}$ & $\begin{array}{l}0.631^{* * * *} \\
(0.0695)\end{array}$ \\
\hline Log (Labour Force) & $\begin{array}{r}0.0981 \\
(0.0632)\end{array}$ & $\begin{array}{r}0.635^{* * *} \\
(0.113)\end{array}$ \\
\hline Log(GDP Per Capita) & $\begin{array}{r}-0.0492 \\
(0.0999)\end{array}$ & $\begin{array}{r}-0.358 * * \\
(0.178)\end{array}$ \\
\hline Political Instability & $\begin{array}{l}-0.0286 \\
(0.0222)\end{array}$ & $\begin{array}{r}-0.332 * * * \\
(0.0629)\end{array}$ \\
\hline Corruption perception index & $\begin{array}{r}-0.0311 \\
(0.0787)\end{array}$ & $\begin{array}{r}-1.049 * * * \\
(0.166)\end{array}$ \\
\hline Inflation rate & $\begin{array}{l}0.0240 * * * \\
(0.00808)\end{array}$ & $\begin{array}{r}0.000550 \\
(0.0265)\end{array}$ \\
\hline Constant & $\begin{array}{r}0.149 \\
(1.276)\end{array}$ & $\begin{array}{r}4.791^{*} \\
(2.465)\end{array}$ \\
\hline Hansen J test & 185.45 & \\
\hline P-value & 0.51 & \\
\hline Observations & 172 & 172 \\
\hline Number of $\mathrm{N}$ & 6 & 6 \\
\hline
\end{tabular}


Adopting the IV approach, the argument that natural resources (Oil) deters the foreign investors from involvement to the GCC countries still holds. Table 3 shows that FDI inflows respond adversely to oil dependence degree by $0.89 \%$. In order to control for the effect of the business cycle, we estimate the model again using a five- year mean interval, which reduces the co-movement biases and the effect of measurement error (Acemoglu, Johnson, Robinson, \& Yared, 2008; Islam, 1995). The estimation indicates that the impact of natural resources dependence on FDI become bigger compared with annual results and is still negative.

These empirical results are confirmed by small parallel literature on the impact of natural resources on FDI. Previous studies concluded that there is negative relationship between natural resource endowment and foreign firm's decision. Asidue (2013) used oil exports as a proxy for natural resources while Poelhekke and Van der Ploeg (2013) measure natural resources by oil assets. However, our paper uses oil rents as a variable for resource abundance.

The possible reasons behind this negative correlation between FDI and abundance of FDI are; first, the idea that resource booms lead to an appreciation of local currency. As a result the country's exports will be less competitive at world prices, and thereby crowds out investments in non-natural resource tradable sectors. The second explanation is that natural resources, particularly oil, are characterized by booms and busts, leading to increased volatility in the exchange rate (Sachs \& Warner, 1995). Additionally, a higher degree of oil dependence implies less trade diversification, which in turn makes a country more vulnerable to external shocks. Lastly, FDI in natural resource endowed countries tends to be concentrated in the resource sector, which creates unbalanced sectoral FDI and increases the crowding out effect.

\begin{tabular}{|c|c|c|}
\hline & (5) & (7) \\
\hline $\begin{array}{l}\text { Variables } \\
\text { Dependent variable: } \log (\mathrm{FDI})\end{array}$ & Fixed Effect model & $\begin{array}{r}\text { Instrumental Variables } \\
\text { estimator }\end{array}$ \\
\hline Log(Oil revenues) & $\begin{array}{r}-0.987^{* *} \\
(0.438)\end{array}$ & $\begin{array}{r}-0.244 \\
(0.633)\end{array}$ \\
\hline Log(openness) & $\begin{array}{r}0.528 * * \\
(0.213)\end{array}$ & $\begin{array}{r}0.569^{* * *} \\
(0.162)\end{array}$ \\
\hline Log(Labour Force) & $\begin{array}{r}1.235^{* * *} \\
(0.219)\end{array}$ & $\begin{array}{r}0.902 * * * \\
(0.230)\end{array}$ \\
\hline Log(GDP Per Capita) & $\begin{array}{l}0.973^{*} \\
(0.543)\end{array}$ & $\begin{array}{r}1.076 * * \\
(0.518)\end{array}$ \\
\hline Constant & $\begin{array}{r}-17.26 * * * \\
(5.380)\end{array}$ & $\begin{array}{r}-18.53^{* * *} \\
(5.460)\end{array}$ \\
\hline Observations & 42 & 36 \\
\hline R-squared & 0.726 & \\
\hline Number of $\mathrm{N}$ & 6 & 6 \\
\hline
\end{tabular}

\subsection{CONCLUSION}

This paper has been stimulated by the decline of FDI to the resource sector in the particular the primary sector. In the line with the Dutch disease model of Cordon and Neary (1982) based on the natural resources curse hypothesis (Sachs and Warner,1995). The main hpothesis of this study has been accepted that there is adverse association between FDI and resource abundance in GCC countries. This paper has empirically provide evidence for negative association between natural resources and FDI inflows in six GCC countries using panel data models. The main findings of this paper are that FDI inflow-GDP ratio is 
negatively correlated with natural resource abundance, which is consistent with the hypothesis of FDINatural resource curse (Asidue 2013). This phenomenon can be attributed to the crowding out the effect of resource sector and the impact of oil price volatility. Also, the paper concludes that trade openness and labour force is one of the main factors for attracting Multinational Corporations, while political instability and corruption deter foreign investors from involvment in GCC countries.

The main policy implications of this study for resource-rich economies generally and GCC countries in paricular are as follows; firslty, policy makers should redce dependence on the oil sector. Table (05) indicates that oil GDP constiutes for more than 50\% of total GDP in GCC countries(World Bank dataset) (World Bank, 2015). This makes GCC countries more prone to rent-seeking activities and any fluctautions in oil prices will effect negatively on these economies. Secondly, to minimize the negative impact of natural resources on FDI, govenmnets should think about ways to distibute FDI to different sectors such as the financial and trorsim sectors. This may improve the compitiveness of non-oil sectors. GCC countries ranked in the bottom in terms of FDI and techonology tansfer compititveness.

Future research is needed to fully understand the force behind the negative relationship between FDI and natural resources and it would be very beneficial to use sectoral analysis of FDI to reveal the mechanism of this impact. The main limitation of this study could small number of sample; one would expand the region to include MENA or OPEC countries.

Table 5: Structure of GDP in GCC countries

Country Oil GDP/GDP $\%$ (Average of 1980-2013)

United Arab Emirates

Qatar 56.13

Oman 53.15

Kuwait 52.96

Bahrain

Kingdom of Saudi Arabia

Average GCC countries(1980-2013)

Source: Author's work depending on data from World Bank

\section{REFERENCES}

Acemoglu, D., Johnson, S., Robinson, J. A., \& Yared, P. (2008). Income and democracy. The American Economic Review, 98(3), 808-842.

Alfaro, L. (2003). Foreign direct investment and growth: Does the sector matter?. Harvard Business School, 1-31.

Arellano, M., \& Bond, S. (1991). Some tests of specification for panel data: Monte Carlo evidence and an application to employment equations. The Review of Economic Studies, 58(2), 277-297.

Asiedu, E. (2006). Foreign direct investment in Africa: The role of natural resources, market size, government policy, institutions and political instability. The World Economy, 29(1), 63-77.

Asiedu, E. (2013). Foreign direct investment, natural resources and institutions. Retrieved from London: International Growth Center. http://www.theigc.org/wp-content/uploads/2014/og/Asiedu-2013Working-Paper.pdf

Asiedu, E., \& Lien, D. (2011). Democracy, foreign direct investment and natural resources. Journal of international economics, 84(1), 99-111.

Blundell, R., \& Bond, S. (1998). Initial conditions and moment restrictions in dynamic panel data models. Journal of econometrics, 87(1), 115-143.

Bokpin, G. A., Mensah, L., \& Asamoah, M. E. (2015). Foreign direct investment and natural resources in Africa. Journal of Economic Studies, 42(4), 608-621. doi:doi:10.1108/JES-01-2014-0023

Cameron, A. C. (2010). Microeconometrics using stata (Vol. 2): Stata Press College Station, TX. 
Corden, W. M., \& Neary, J. P. (1982). Booming sector and de-industrialisation in a small open economy. The Economic Journal, 825-848.

Hailu, Z. A. (2010). Demand side factors affecting the inflow of foreign direct investment to African countries: does capital market matter? International Journal of Business and Management, 5(5), 104.

Islam, N. (1995). Growth empirics: a panel data approach. The Quarterly Journal of Economics, 1127-1170.

Kinoshita, Y., \& Campos, N. F. (2003). Why does FDI go where it goes? New evidence from the transition economies.

Mina, W. (2007). The location determinants of FDI in the GCC countries. Journal of Multinational Financial Management, 17(4), 336-348. Retrieved from http://ac.els-cdn.com/S1042444X07000151/1-s2.0S1042444X07000151-main.pdf?_tid=a833e03e-421c-11e6-81cd-00000aacb35d\&acdnat $=1467660333$ 1fd6ec187bao4e97215bodde7eze221e

Poelhekke, S., \& Van der Ploeg, R. (2010). Do Natural Resources Attract FDI? Evidence from non-stationary sector level data.

Poelhekke, S., \& van der Ploeg, R. (2013). Do Natural Resources Attract Nonresource FDI? The Review of Economics and Statistics, 95(3), 1047-1065.

Sachs, J. D., \& Warner, A. M. (1995). Natural resource abundance and economic growth(No. w5398).National Bureau of Economic Research http://www.nber.org/papers/w5398

Schwab, K., \& Sala-i-Martin, X. (2015). The Global Competitiveness Report. Worl Economic forum UNCTAD. (2015). World Investment Report. Geneva:United Nations

World Bank. (2015). World Economic Indicators. Retrieved on 25-07-2015

\section{APPENDICES}

\begin{tabular}{ll}
\hline & Appendix A: Variable definition and data sources. \\
\hline Variable & source \\
\hline FDI inflow stock & United Nations Conference on Trade and Development \\
GDP per capita & United Nations Conference on Trade and Development \\
Oil rents & World Bank \\
Tarde openness & World Bank \\
Inflation rate & World Bank \\
Political instability & International Country Risk Guide \\
Corruption perception index & International Country Risk Guide \\
\hline
\end{tabular}

\begin{tabular}{|c|c|c|c|c|}
\hline \multicolumn{5}{|c|}{ Appendix B: Panel unit root } \\
\hline variable & $\mathrm{LLC}^{4}$ & IPS $^{5}$ & $\mathrm{ADF}^{6}$ & $\mathrm{PP}^{7}$ \\
\hline $\mathrm{D}(1) \log (\mathrm{FDI} / \mathrm{GDP})$ & $-1.76 * * *$ & $-5.61 * * *$ & $53.88 * * *$ & $117 \cdot 37 * * *$ \\
\hline D(1)Log(Oil Rents/GDP) & $-10.93 * * *$ & $-10.75 * * *$ & $112.75 * * *$ & $148.60 * * *$ \\
\hline D(1)Log(trade openness) & $-5 \cdot 35 * * *$ & $-7.28 * * *$ & $71.20 * * *$ & $120.00 * * *$ \\
\hline D(1)Log(labour force) & $-1.93^{* * *}$ & $-2.91 * * *$ & $28.30 * * *$ & $17 \cdot 52 * * *$ \\
\hline D(1)Log(GDP Per capita) & $-5.03 * * *$ & $-5.69 * * *$ & $57.69 * * *$ & $67.08 * * *$ \\
\hline \multicolumn{5}{|l|}{ D(1) (Inflation Rate) } \\
\hline D(1) (Political Instability) & $-4.48 * * *$ & $-4.89 * * *$ & $46.68 * * *$ & $71.34 * * *$ \\
\hline$D(1)$ Corruption & $-5 \cdot 57^{* * *}$ & $-4.10 * * *$ & $35.14 * * *$ & $60.20 * * *$ \\
\hline
\end{tabular}

\footnotetext{
4 Levin, Lin and Chu

5 Im-Pasaran-Shin

${ }^{6}$ Augmented Dick-Fuller

7 Phlips-Perron
} 


\begin{tabular}{|c|c|c|c|}
\hline \multicolumn{4}{|c|}{ Appendix C. Panel co-integration test } \\
\hline \multicolumn{4}{|l|}{ Kao test } \\
\hline & & Prob & Decision \\
\hline & 86 & 0.03 & Co-integration \\
\hline \multicolumn{4}{|c|}{ Johansen -Fisher panel co-integration } \\
\hline Hypothesis & $\begin{array}{r}\text { Fisher statistics } \\
\text { (trace test) }\end{array}$ & $\begin{array}{r}\text { Fisher statistics } \\
\text { (max-Eigen test) }\end{array}$ & Prob \\
\hline Non & 308.6 & 204.3 & 0.0000 \\
\hline At most 1 & 185.4 & 89.45 & 0.0000 \\
\hline At most 2 & 110.3 & 51.55 & 0.0000 \\
\hline At most 3 & 67.59 & 35.14 & 0.0004 \\
\hline At most 4 & 40.60 & 27.23 & 0.0072 \\
\hline At most 5 & 24.24 & 22.95 & 0.0281 \\
\hline At most 6 & 16.50 & 16.50 & 0.1693 \\
\hline
\end{tabular}

It is clear that Null hypothesis Ho: unit root in common sample and individuals is rejected in first difference for all variables, which means all variables are stationary at first difference and integrated from the same order I(1). As a result, co-integration may exist between variables. After applying the Kao test and Johansen-Fisher test, it is obvious that there is co-integration between variables, means that there is a long run relationship. 